\title{
Red blood cell distribution width (RDW) in Hospitalized COVID-19 Patients
}

\section{Running title: RDW and COVID-19}

Names of authors with address

\section{1) Preethi Ramachandran MD, MRCP, FRCPath}

Brookdale University Hospital and Medical center

Brooklyn, NY 11212 USA

Phone: 7182406206

Fax- 7182406516

Email: drpreethiram@hotmail.com

2) Mahesh Gajendran, MD, MPH, FACP

Texas Tech University, Paul L Foster School of Medicine

El Paso, Texas 79905, USA

Phone number: 915-215-8000

Fax Number: 915-612-9254

Email: mahesh.gajendran@ttuhsc.edu

3) Abhilash Perisetti, MD FACP

Department of Gastroenterology and Hepatology

University of Arkansas for Medical Sciences

Little Rock, AR, USA

Email: abhilash.perisetti@gmail.com

4) Karim Osama Elkholy, MD

Department of Internal Medicine,

Brookdale University Hospital and Medical center,

Brooklyn, NY- 11212 USA

Phone: 7182406206

Fax- 7182406516

Email: Kelkholy@bhmcny.org

5) Abhishek Chakraborti, MD

Department of Internal Medicine,

Brookdale University Hospital and Medical center, Brooklyn, NY- 11212 USA

Phone: 7182406206 
Fax- 7182406516

Email: Abhishek c@outlook.com

\section{6) "Prof. Giuseppe Lippi}

Full Professor of Clinical Biochemistry, University of Verona

Director, Laboratory of Clinical Chemistry and Hematology,

University Hospital of Verona

Tel. +39-045-8124308

Email: giuseppe.lippi@univr.it

\section{7) "Hemant Goyal, MD FACP}

The Wright Center for Graduate Medical Education

$501 \mathrm{~S}$. Washington Avenue

Scranton, PA 18503 USA

Office: 570.591 .5175

Email: doc.hemant@yahoo.com

\# These authors share senior authorship in this work.

Word count: 1904

Abstract Word count: 234

Corresponding author:

Hemant Goyal, MD FACP PGDCA (MBA)

The Wright Center for Graduate Medical Education

501 S. Washington Avenue

Scranton, PA 18505 USA

Office: 570.591 .5175

Email: doc.hemant@yahoo.com

Acknowledgments- None 


\section{Red blood cell distribution width (RDW) in Hospitalized COVID-19 Patients}

\section{Abstract}

Introduction: Coronavirus disease-2019 (COVID-19), caused by severe acute respiratory syndrome coronavirus-2 (SARS-CoV-2), is causing dramatic morbidity and mortality worldwide. The Red Blood Cell Distribution Width (RDW) has been strongly associated with increased morbidity and mortality in multiple diseases.

Objective: To assess if elevated RDW is associated with unfavorable outcomes in hospitalized COVID-19.

Methods: We retrospectively studied clinical outcomes of hospitalized COVID-19 patients for their RDW values. In-hospital mortality was defined as primary outcome, while septic shock, need for mechanical ventilation, and length of stay (LOS) were secondary outcomes.

Results- A total of 294 COVID-19 patients were finally studied. Overall prevalence of increased RDW was $49.7 \%$ (146/294). RDW was associated with increased risk of in-hospital mortality (aOR, 4.5; 95\%Cl, 1.4-14.3) and septic shock (aOR, 4.6; 95\% $\mathrm{Cl}, 1.4-15.1$ ) after adjusting for anemia, ferritin, and lactate. The association remained unchanged even after adjusting for other clinical confounders such as age, sex, body mass index, coronary artery disease, hypertension, diabetes mellitus, and chronic obstructive pulmonary disease. No association was found instead with mechanical ventilation and median LOS.

Conclusion: Elevated RDW in hospitalized COVID-19 patients is associated with a significantly increased risk of mortality and septic shock.

Keywords- COVID-19; Red Cell Distribution Width; RDW; SARS-CoV-2; septic shock; mortality; length of stay. 
medRxiv preprint doi: https://doi.org/10.1101/2020.06.29.20143081; this version posted July 3, 2020. The copyright holder for this preprint (which was not certified by peer review) is the author/funder, who has granted medRxiv a license to display the preprint in perpetuity. It is made available under a CC-BY-NC-ND 4.0 International license .

\section{Introduction}

The ongoing Coronavirus Disease 2019 (COVID-19) pandemic, caused by severe acute respiratory syndrome corona virus-2 (SARS-CoV-2), has started as a cluster of pneumonia-like illness in Wuhan, China, and has now spread all around the world [1]. During the initial outbreak of COVID-19, respiratory involvement was the primary cause of morbidity and mortality. As of June 18, 2020, COVID-19 had infected over 9 million people, causing 450,000 deaths, and numbers continue to rise [2]. As the number of patients increased, other organ system involvement were increasingly recognized [3-8]. The US Center for Disease Control and Prevention $(C D C)$ emphasizes that patients with preexisting conditions such as advanced age (65 years or older) or pathologies like cardiovascular disease, diabetes, cancer, hypertension, chronic obstructive pulmonary disease (COPD) are at higher risk of COVID-19-associated morbidity and mortality [9].

It is now unquestionable that early identification and prompt management of COVID-19 could prevent or delay the onset of life-threatening complications. In addition to preexisting conditions, the use of prognostic laboratory biomarkers may be of great clinical significance for identifying patients at higher risk of worse progression. Similar to other viral illnesses, COVID-19 is associated with leukopenia, lymphopenia, and elevated values of many traditional inflammatory biomarkers $[10,11]$.

RDW is an inexpensive measure of erythrocyte size variation, and it can be used in the differential diagnosis of hematological disturbances such as iron deficiency anemia and bone marrow dysfunction [12]. This parameter is calculated as the standard deviation (SD) of red blood cell (RBC) volume, divided by the mean corpuscular volume (MCV), thus providing a quantitative estimation of anisocytosis. Alteration of erythropoiesis can result in extensive heterogeneity of RBC size, which can provide indirect evidence of existing and ongoing pathological changes. In inflammatory states, the turnover of the RBC is decreased, with a simultaneous increase of inflammatory cell turnover (e.g., leukocytes and platelets) in the attempt to counteract the infection [13]. Due to these changes, RDW is usually elevated in 
medRxiv preprint doi: https://doi.org/10.1101/2020.06.29.20143081; this version posted July 3, 2020. The copyright holder for this preprint (which was not certified by peer review) is the author/funder, who has granted medRxiv a license to display the preprint in perpetuity. It is made available under a CC-BY-NC-ND 4.0 International license .

conditions such as advanced age, diabetes, cardiovascular diseases, gastrointestinal disorders, infections, and a vast array of infections and inflammatory states [14-18].

As the pathogenesis of COVID-19 involves both infection and inflammation, the RDW measured at hospital admission could potentially be considered a reliable index for identifying patients at higher risk of an unfavorable outcome [19]. Therefore, this study was aimed at exploring whether RDW value upon admission may predict clinical progression in patients hospitalized for COVID-19.

\section{Methods}

This retrospective descriptive study was carried out from a single tertiary care academic medical center in New York City. The study was approved by the institutional review board.

The initial study population consisted of all consecutive adult patients admitted to the hospital with confirmed SARS-CoV-2 infection from January 20, 2020, to April 25, 2020. The study cohort was stratified into two groups according to the RDW value (elevated, cases; normal, controls). The RDW is measured using the Beckman Coulter analyzer. Elevated RDW was defined as a value $>14.6 \%$, which is the upper limit of the healthy adult reference interval in the local institution. Inclusion criteria included all adult patients (age $\geq 18$ years) hospitalized for COVID-19, thus testing positive for SARS-CoV-2 on the nasopharyngeal swab, according to current guidelines [20]. Exclusion criteria were- individuals who were not hospitalized or treated on an ambulatory basis, age $<18$ years, pregnancy, non-availability of nasopharyngeal testing, lack of clinical or laboratory information on disposition and/or mortality data anemia was defined as a hemoglobin value $<130 \mathrm{~g} / \mathrm{L}$ in males and $<120 \mathrm{~g} / \mathrm{L}$ in females, respectively.

Information on patient demographics, presenting symptoms, comorbidities, home medications, and initial laboratory tests were obtained at hospital admission. In-hospital mortality from any cause was defined as the primary outcome in this study, whilst septic shock, need for mechanical ventilation, and in-hospital length of stay (LOS) were secondary outcomes. Statistical analysis was performed using IBM SPSS software version 26 (SPSS Inc, Armonk, NY). Descriptive summary statistics are shown as median with interquartile range (IQR) for continuous variables since most were not normally distributed, and frequencies with 
medRxiv preprint doi: https://doi.org/10.1101/2020.06.29.20143081; this version posted July 3, 2020. The copyright holder for this preprint (which was not certified by peer review) is the author/funder, who has granted medRxiv a license to display the preprint in perpetuity. It is made available under a CC-BY-NC-ND 4.0 International license .

percentages for categorical variables. Categorical and continuous variables were tested for statistical significance using chi-square tests and t-tests, respectively. We performed two models of multivariable logistic regression analyses. In the first model, we included variables with $\mathrm{P}<0.05$ from univariate analysis. In the second model, we also included other clinically relevant variables such as age, sex, body mass index (BMI), coronary artery disease (CAD), hypertension, diabetes mellitus, and chronic obstructive pulmonary disease (COPD). The results of the regression models were provided as adjusted odds ratio (aOR) and its $95 \%$ confidence interval $(\mathrm{Cl})$. The receiver operating characteristic (ROC) curve was used for exploring the discriminant power of the model.

\section{Results}

The initial study population consisted of 300 patients hospitalized for COVID-19, six of whom ought to be excluded due to undefined results of SARS CoV-2 testing and lack of key outcome variables. Therefore, a final number of 294 patients composed the final study population (Figure 1). The prevalence of elevated RDW values was found to be $49.7 \%(146 / 294)$.

3.1 Baseline demographics - Baseline demographic data and comorbidities in patients with or without elevated RDW value are summarized in Table 1. Patients with elevated RDW were older (median age, 66 vs. 63 years; $p=0.02$ ), with female predominance ( $52 \%$ vs. 38\%; $p=0.02$ ). Patients with elevated RDW value had also a higher prevalence of hypertension (79.5\% vs. $62.8 \% ; p=0.002)$, CAD (19.9\% vs. $10.8 \% ; p=0.04)$ and COPD (13\% vs. $5.4 \% ; p=0.03)$.

3.2 Laboratory data- Laboratory data at the time of admission in patients with or without elevated RDW value are summarized in Table 2. The prevalence of anemia was higher in patients with increased RDW value than in those without $(58.2 \%$ vs. $33.1 \%$; $p<0.001)$. Elevated lactate values were also more frequent in patients with increased RDW value than in those without (48.3\% vs. $33.1 \% ; p=0.018)$. The rate of abnormal values of lymphocyte count, platelet count, D-dimer, C reactive protein (CRP), aminotransferases, bilirubin, and alkaline phosphatase did not differ between the two cohorts of patients.

3.3 Outcomes- The outcomes of the study are shown in Table 3. The COVID-19 patients with elevated RDW value had a higher frequency of in-hospital mortality compared to those with 
medRxiv preprint doi: https://doi.org/10.1101/2020.06.29.20143081; this version posted July 3, 2020. The copyright holder for this preprint (which was not certified by peer review) is the author/funder, who has granted medRxiv a license to display the preprint in perpetuity. It is made available under a CC-BY-NC-ND 4.0 International license .

normal RDW value, but the difference was not statistically significant ( $23.3 \%$ vs. $15.1 \%, P=0.1)$. However, after adjusting for lactate, ferritin, and anemia, elevated RDW was found to be significantly associated with a higher risk of in-hospital mortality (aOR 4.5, 95\% Cl 1.44-14.28; $\mathrm{p}=0.01)$. The incidence of shock was also higher in the elevated RDW group $(37.7 \%$ vs. $25.7 \%$; $\mathrm{p}=0.03$ ) compared to patients with normal RDW values. Elevated RDW was associated with a 4.6-fold higher odds of shock (aOR 4.6, 95\% Cl 1.43-15.08; $p=0.01$ ) after adjusting for confounders. No association with RDW value was found for the need for mechanical ventilation or in-hospital (LOS).

3.4 Analysis by ROC- The ROC area under the curve (AUC) was found to be 0.85 and 0.77 for predicting mortality (Figure 2A) and septic shock (Figure 2B), respectively. It had a sensitivity of $70 \%$ in predicting both mortality and septic shock.

\section{Discussion}

Based on our study, nearly half (49.7\%) of patients hospitalized for COVID-19 were found to have elevated RDW values at presentation. Patients with increased RDW, and thereby more significant anisocytosis, had increased risk of in-hospital mortality and septic shock compared to those with normal values. These findings remained significant after adjusting for potential confounders. On the other hand, we failed to find a significant association between RDW and the need for mechanical ventilation and LOS.

RDW increases with age, especially among females [21]. This is probably due to decreased RBC deformability developing in parallel with aging. Similarly, RDW is identified as an important risk factor in the diagnosis and prognosis of patients with cardiovascular disease (CVD) [12]. While the precise mechanism remains speculative, a combination of RDW and validated cardiac markers can help to identify patients with CVD earlier, thus allowing them to establish more appropriate and targeted management. Our study showed a similar prevalence of higher RDW with older age and female sex among cases compared to controls. Furthermore, the presence of hypertension and CAD was higher in patients with increased $\operatorname{RDW}[22,23]$, and this is in keeping with earlier studies and is also representative of populations with preexisting health conditions $[13,14,21]$. 
medRxiv preprint doi: https://doi.org/10.1101/2020.06.29.20143081; this version posted July 3, 2020. The copyright holder for this preprint (which was not certified by peer review) is the author/funder, who has granted medRxiv a license to display the preprint in perpetuity. It is made available under a CC-BY-NC-ND 4.0 International license .

The precise mechanism by which RDW elevation develops in COVID-19 patients is unclear. Prior studies showed an association of elevated RDW with increased inflammatory markers, oxidative stress with impaired iron metabolism, which would ultimately promote RBC apoptosis, and variance in their morphology $[13,24,25]$. COVID-19 patients are known to have a significant inflammatory response, which can lead to multiorgan failure. It is unclear if increased RDW in COVID-19 patients is due to this inflammatory response [26]. It is well known that SARS-CoV-2 enters human cells via angiotensin-converting enzyme 2 (ACE-2) [27]. The expression of ACE-2 varies significantly among organs and tissues, and this would contribute to explaining the different degrees of the vulnerability of host cells to viral entry and cytopathic effects [28]. The use of medications such as ACEI/ARB in our study was higher in cases compared to controls ( $37 \%$ vs. $26.4 \%$; $p=0.06$ ) but did not reach statistical significance. It can, at least in part, explain the gastrointestinal manifestations such as nausea, vomiting, diarrhea and abnormal liver tests in patients with enhanced RDW values.

Higher admission RDW may reflect the presence of ongoing chronic and severe inflammation. Some patients with COVID-19 develop a cytokine storm syndrome, characterized by overproduction of early response pro-inflammatory cytokines such as tumor necrosis factor, interleukin [IL]-6, and IL-1及 [26]. It can lead to increased vascular permeability, hyperinflammation, and loss of procoagulant-anticoagulant balance [26]. Our study showed an increased level of lactate in patients with RDW values above the normal threshold, thus correlating with the increased incidence of shock and mortality. The increased RDW was found to be independently associated with a higher incidence of shock and mortality after adjusting for all the confounding variables. Whether higher RDW can predict rates of altered hemodynamics and early features of shock in these patients is unclear and remains to be studied.

RDW has been previously studied in patients with severe sepsis and septic shock. Wang et al. noted that higher levels of RDW was an independent predictor of in-hospital mortality in elderly patients with sepsis, and could potentially be used as a reliable biomarker for predicting clinical outcomes [29]. RDW has also been used as a prognostic biomarker for predicting 28-day 
medRxiv preprint doi: https://doi.org/10.1101/2020.06.29.20143081; this version posted July 3, 2020. The copyright holder for this preprint (which was not certified by peer review) is the author/funder, who has granted medRxiv a license to display the preprint in perpetuity. It is made available under a CC-BY-NC-ND 4.0 International license.

mortality in patients with severe sepsis and septic shock [30, 31]. Recently Foy et al. showed that elevated RDW at diagnosis, as well as its increase during the hospitalization, was associated with an increased risk of mortality in patients with COVID-19 [32], thus supporting our evidence. Nonetheless, the need for mechanical ventilation and the LOS did not differ between cases and controls, and this probably attributable due to adequate resuscitative efforts enabled by an early risk stratification. In addition, other markers of inflammation such as D-dimer, leukocytosis, C-reactive protein (CRP) did not differ significantly according to the RDW threshold, thus paving the way to further studies aimed at precisely establishing the role of anisocytosis in the pathogenesis of COVID-19.

\section{Conclusion}

Elevated RDW is a common finding in patients hospitalized for COVID-19. The preliminary findings of this study show that elevated RDW at admission is present in almost half of patients, and independently predicts shock and mortality but not LOS or need for mechanical ventilation. 
medRxiv preprint doi: https://doi.org/10.1101/2020.06.29.20143081; this version posted July 3, 2020. The copyright holder for this preprint (which was not certified by peer review) is the author/funder, who has granted medRxiv a license to display the preprint in perpetuity. It is made available under a CC-BY-NC-ND 4.0 International license .

\section{References}

[1] C. Huang, Y. Wang, X. Li, L. Ren, J. Zhao, Y. Hu, L. Zhang, G. Fan, J. Xu, X. Gu, Z. Cheng, T. Yu, J. Xia, Y. Wei, W. Wu, X. Xie, W. Yin, H. Li, M. Liu, Y. Xiao, H. Gao, L. Guo, J. Xie, G. Wang, R. Jiang, Z. Gao, Q. Jin, J. Wang, B. Cao, Clinical features of patients infected with 2019 novel coronavirus in Wuhan, China, Lancet 395(10223) (2020) 497-506.

[2] J. Worldometer, 2020., Coronavirus Update (Live): 7,369,015 Cases and 414,845 Deaths from COVID19 Virus Pandemic - Worldometer, 2020. https://www.worldometers.info/coronavirus/\#countries.

[3] M. Aziz, A. Perisetti, W. Lee-Smith, M. Gajendran, P. Bansal, H. Goyal, Taste Changes (Dysgeusia) in COVID-19: A Systematic Review and Metaanalysis, Gastroenterology S0016-5085(20) (2020) 30595-3.

[4] J. Kopel, A. Perisetti, M. Gajendran, U. Boregowda, H. Goyal, Clinical Insights Into the Gastrointestinal Manifestations of COVID-19, Digestive diseases and sciences 1-8 (2020).

[5] C. Gadiparthi, A. Perisetti, H. Sayana, B. Tharian, S. Inamdar, A. Korman, Gastrointestinal Bleeding in Patients With Severe SARS-CoV-2, The American journal of gastroenterology (2020).

[6] M. Aloysius, A. Thatti, A.e.a. Gupta, COVID-19 presenting as acute pancreatitis, Pancreatology S14243903(20) (2020) 30154 .

[7] S. Zaim, J. Chong, V. Sankaranarayanan, H. A, COVID-19 and Multiorgan Response, Current problems in cardiology 45(8) (2020).

[8] A. Perisetti, M. Gajendran, U. Boregowda, P. Bansal, H. Goyal, COVID-19 and gastrointestinal endoscopies: current insights and emergent strategies, Dig Endosc (2020).

[9] CDC, People Who Are at Higher Risk for Severe Illness I CDC, 2020, April 15. https://www.cdc.gov/coronavirus/2019-ncov/need-extra-precautions/people-at-higher-risk.html.

[10] K. Boonnak, L. Vogel, F. Feldmann, H. Feldmann, K. Legge, K. Subbarao, Lymphopenia Associated With Highly Virulent H5N1 Virus Infection Due to Plasmacytoid Dendritic Cell-Mediated Apoptosis of T Cells, Journal of immunology (Baltimore, Md. : 1950) 192(12) (2014).

[11] L. Tan, Q. Wang, D. Zhang, J. Ding, Q. Huang, Y. Tang, W. Q, M. H, Lymphopenia Predicts Disease Severity of COVID-19: A Descriptive and Predictive Study, Signal transduction and targeted therapy 5(1) (2020).

[12] H. Alcaíno, J. Pozo, M. Pavez, H. Toledo, [Red Cell Distribution Width as a Risk Marker in Patients With Cardiovascular Diseases], Revista medica de Chile 144(5) (2016).

[13] G. Salvagno, F. Sanchis-Gomar, A. Picanza, G. Lippi, Red Blood Cell Distribution Width: A Simple Parameter With Multiple Clinical Applications, Critical reviews in clinical laboratory sciences 52(2) (2015). 
medRxiv preprint doi: https://doi.org/10.1101/2020.06.29.20143081; this version posted July 3, 2020. The copyright holder for this preprint (which was not certified by peer review) is the author/funder, who has granted medRxiv a license to display the preprint in perpetuity. It is made available under a CC-BY-NC-ND 4.0 International license .

[14] G. Lippi, C. Mattiuzzi, G. Cervellin, Learning More and Spending Less With Neglected Laboratory Parameters: The Paradigmatic Case of Red Blood Cell Distribution Width, Acta bio-medica : Atenei Parmensis 87(3) (2016).

[15] H. Goyal, G. Lippi, A. Gjymishka, B. John, R. Chhabra, E. May, Prognostic significance of red blood cell distribution width in gastrointestinal disorders, World journal of gastroenterology 23(27) (2017) 4879-4891.

[16] Y. Han, L. Yan, L. Zhang, P. Ouyang, P. Li, H. Goyal, H. ZD, Red Blood Cell Distribution Width Provides Additional Prognostic Value Beyond Severity Scores in Adult Critical Illness, Clinica chimica acta; international journal of clinical chemistry 498 (2019).

[17] H. Goyal, Z. Hu, Prognostic Value of Red Blood Cell Distribution Width in Hepatocellular Carcinoma, Annals of translational medicine 5(13) (2017).

[18] H. Goyal, S. Gupta, U. Singla, Level of Red Cell Distribution Width Is Affected by Various Factors, Clinical chemistry and laboratory medicine 54(12) (2016).

[19] G. Lippi, F. Sanchis-Gomar, B.M. Henry, COVID-19: unravelling the clinical progression of nature's virtually perfect biological weapon, Annals of Translational Medicine 8(11) (2020) 693.

[20] M.K. Bohn, G. Lippi, A. Horvath, S. Sethi, D. Koch, M. Ferrari, C.-B. Wang, N. Mancini, S. Steele, K. Adeli, Molecular, serological, and biochemical diagnosis and monitoring of COVID-19: IFCC taskforce evaluation of the latest evidence, Clinical Chemistry and Laboratory Medicine (CCLM) 1(ahead-of-print) (2020).

[21] G. Lippi, G. Salvagno, G. Guidi, Red Blood Cell Distribution Width Is Significantly Associated With Aging and Gender, Clinical chemistry and laboratory medicine 52(9) (2014).

[22] M. Tonelli, F. Sacks, M. Arnold, L. Moye, B. Davis, P. M, Relation Between Red Blood Cell Distribution Width and Cardiovascular Event Rate in People With Coronary Disease, Circulation 117(2) (2008).

[23] S. Seo, M. Lee, S. Park, J. Han, K. Lee, H. Kim, H. YY, The Association Between Red Cell Distribution Width and Incident Hypertension in Korean Adults, Hypertension research : official journal of the Japanese Society of Hypertension 43(1) (2020).

[24] J. Friedman, M. Lopez, M. Fleming, A. Rivera, F. Martin, M. Welsh, A. Boyd, D. SR, B. SJ, SOD2deficiency Anemia: Protein Oxidation and Altered Protein Expression Reveal Targets of Damage, Stress Response, and Antioxidant Responsiveness, Blood 104(8) (2004).

[25] G. Weiss, L. Goodnough, Anemia of Chronic Disease, The New England journal of medicine 352(10) (2005). 
medRxiv preprint doi: https://doi.org/10.1101/2020.06.29.20143081; this version posted July 3, 2020. The copyright holder for this preprint (which was not certified by peer review) is the author/funder, who has granted medRxiv a license to display the preprint in perpetuity. It is made available under a CC-BY-NC-ND 4.0 International license.

[26] R. Jose, A. Manuel, COVID-19 Cytokine Storm: The Interplay Between Inflammation and Coagulation, The Lancet. Respiratory medicine (2020).

[27] X. Chai, L. Hu, Y. Zhang, W. Han, Z. Lu, A. Ke, J. Zhou, G. Shi, N. Fang, J. Fan, J. Cai, J. Fan, F. Lan, Specific ACE2 Expression in Cholangiocytes May Cause Liver Damage After 2019-nCoV Infection, (2020).

[28] X. Zou, K. Chen, J. Zou, P. Han, J. Hao, Z. Han, Single-cell RNA-seq data analysis on the receptor ACE2 expression reveals the potential risk of different human organs vulnerable to 2019-nCoV infection, Front Med (2020).

[29] A. Wang, H. Ma, W. Kao, S. Tsai, C. CK, Red Blood Cell Distribution Width Is Associated With Mortality in Elderly Patients With Sepsis, The American journal of emergency medicine 36(6) (2018).

[30] A. Jandial, S. Kumar, A. Bhalla, N. Sharma, N. Varma, V. S, Elevated Red Cell Distribution Width as a Prognostic Marker in Severe Sepsis: A Prospective Observational Study, Indian journal of critical care medicine : peer-reviewed, official publication of Indian Society of Critical Care Medicine 21(9) (2017).

[31] Y. Jo, K. Kim, J. Lee, C. Kang, T. Kim, H. Park, K. KW, K. J, R. JE, Red Cell Distribution Width Is a Prognostic Factor in Severe Sepsis and Septic Shock, The American journal of emergency medicine 31(3) (2013).

[32] H.B. Foy, J. Carlson, E.e.a. Reinersten, Preprint- Elevated RDW is Associated with Increased Mortality Risk in COVID-19, (2020). 
medRxiv preprint doi: https://doi.org/10.1101/2020.06.29.20143081; this version posted July 3, 2020. The copyright holder for this preprint (which was not certified by peer review) is the author/funder, who has granted medRxiv a license to display the preprint in perpetuity. It is made available under a CC-BY-NC-ND 4.0 International license.

\section{Figure Legends}

Figure 1: Study Flowchart

Footnotes: COVID-19: Coronavirus Disease 2019; RDW: Red blood cell distribution width

Figure 2 (A): Receiver Operator Curve (ROC) of red blood cell distribution width (RDW) values in coronavirus disease 2019 (COVID-19) patients for predicting mortality

Figure 2 (B): Receiver Operator Curve (ROC) of red blood cell distribution width (RDW) values in coronavirus disease 2019 (COVID-19) patients for predicting septic shock 
Table 1: Baseline demographics of the study population ${ }^{\epsilon}$

\begin{tabular}{|c|c|c|c|}
\hline Characteristic & $\begin{array}{l}\text { RDW Elevated Group } \\
\qquad \mathrm{N}=146\end{array}$ & $\begin{array}{c}\text { RDW normal } \\
\text { Control group } \\
\mathrm{N}=148\end{array}$ & P-value \\
\hline Age, median (IQR), years & $66.1(57,76.3)$ & $63(52,73)$ & 0.02 \\
\hline Age $>60$ years & $105(71.9)$ & $91(61.5)$ & 0.06 \\
\hline Female gender & $76(52.1)$ & $56(37.8)$ & 0.02 \\
\hline BMI, median (IQR), $\mathrm{kg} / \mathrm{m}^{2}$ & $29.1(25.6,34.9)$ & $29.1(25.9,33.9)$ & 0.95 \\
\hline \multicolumn{4}{|l|}{ Race (\%) } \\
\hline White & $3(2.1)$ & $6(2.1)$ & 0.50 \\
\hline African American & $109(74.7)$ & $98(66.2)$ & 0.13 \\
\hline Hispanic & $17(11.6)$ & $22(14.9)$ & 0.49 \\
\hline Asian & $2(1.4)$ & $8(5.4)$ & 0.10 \\
\hline Unknown & $15(10.3)$ & $14(9.5)$ & 0.85 \\
\hline \multicolumn{4}{|l|}{ Comorbidities (\%) } \\
\hline Hypertension & $116(79.5)$ & $93(62.8)$ & 0.002 \\
\hline Dyslipidemia & $49(33.6)$ & $48(32.4)$ & 0.90 \\
\hline CAD & $29(19.9)$ & $16(10.8)$ & 0.04 \\
\hline $\mathrm{DM}$ & $72(49.3)$ & $60(40.5)$ & 0.16 \\
\hline Cancer & $14(9.6)$ & $6(4.1)$ & 0.07 \\
\hline COPD & $19(13)$ & $8(5.4)$ & 0.03 \\
\hline Asthma & $23(15.8)$ & $21(14.2)$ & 0.75 \\
\hline $\begin{array}{l}\text { Immunocompromised } \\
\text { Status (\%) }\end{array}$ & $15(10.3)$ & $9(6.1)$ & 0.21 \\
\hline Smoker (\%) & $17(12.1)$ & $15(10.3)$ & 0.71 \\
\hline \multicolumn{4}{|l|}{ Medications (\%) } \\
\hline ACEI/ARB & $54(37)$ & $29(26.4)$ & 0.06 \\
\hline NSAID & $21(14.7)$ & 24 (16.9) & 0.63 \\
\hline Aspirin & $48(33.6)$ & $40(28.2)$ & 0.37 \\
\hline Statin & $63(44.1)$ & $51(35.9)$ & 0.18 \\
\hline $\mathrm{H} 2 \mathrm{~B}$ & $9(6.2)$ & $8(5.4)$ & 0.81 \\
\hline PPI & $28(19.2)$ & $18(12.2)$ & 0.11 \\
\hline \multicolumn{4}{|l|}{ Symptoms (\%) } \\
\hline Cough & $84(57.5)$ & $93(62.8)$ & 0.40 \\
\hline Fever & $84(57.5)$ & $92(62.2)$ & 0.48 \\
\hline Dyspnea & $104(71.2)$ & $98(66.2)$ & 0.38 \\
\hline Fatigue & $51(34.9)$ & $60(40.5)$ & 0.34 \\
\hline Myalgia & $38(26)$ & $40(27)$ & 0.89 \\
\hline Gl symptom & $20(13.7)$ & $33(22.3)$ & 0.07 \\
\hline Pneumonia (\%) & $137(93.8)$ & $130(87.8)$ & 0.11 \\
\hline
\end{tabular}

BMI: Body mass Index; CAD: Coronary artery disease; DM: Diabetes Mellitus; COPD: Chronic Obstructive Pulmonary disease; ACEl: Angiotensin-converting enzyme inhibitors; ARB: Angiotensin II receptor 
medRxiv preprint doi: https://doi.org/10.1101/2020.06.29.20143081; this version posted July 3, 2020. The copyright holder for this preprint (which was not certified by peer review) is the author/funder, who has granted medRxiv a license to display the preprint in perpetuity.

It is made available under a CC-BY-NC-ND 4.0 International license.

blockers; NSAID: Non-steroidal anti-inflammatorydrugs; H2B: H2 blockers; PPI: Proton Pump Inhibitors; Gl: gastrointestinal

${ }^{€}$ Non-parametric test (Mann-Whitney test) used for non-normal distributed continuous variables, chisquare analysis was used to compare categorical variables.

Table 2: Laboratory data in hospitalized COVID-19 patients according to their red blood cell distribution width (RDW) value

\begin{tabular}{|l|l|l|r|}
\hline \multicolumn{1}{|c|}{ Characteristic } & \multicolumn{1}{|c|}{ RDW Elevated Group } & \multicolumn{1}{c|}{$\begin{array}{c}\text { RDW normal group } \\
\text { N=146 }\end{array}$} & P-value \\
\hline Anemia & $85(58.2)$ & $49(33.1)$ & $<0.001$ \\
\hline Elevated Ferritin & $33 / 44(75)$ & $43 / 47(91.5)$ & 0.048 \\
\hline Elevated D-dimer & $28 / 34(82.4)$ & $30 / 35(85.7)$ & 0.75 \\
\hline Leukocytosis & $39(26.7)$ & $32(21.6)$ & 0.34 \\
\hline Lymphopenia & $88(60.3)$ & $81(54.7)$ & 0.35 \\
\hline Thrombocytopenia & $24(16.4)$ & $37(25)$ & 0.08 \\
\hline Elevated Creatinine & $62(42.5)$ & $48(32.9)$ & 0.17 \\
\hline Hypoalbuminemia & $43(29.5)$ & $37(25.2)$ & 0.43 \\
\hline $\begin{array}{l}\text { Elevated Creatinine } \\
\text { Phosphokinase }\end{array}$ & $9 / 69(13)$ & $11 / 86(12.8)$ & 1.00 \\
\hline Elevated Lactate & $57 / 118(48.3)$ & $40 / 121(33.1)$ & 0.018 \\
\hline Elevated LDH & $124 / 124(100)$ & $128 / 129(99.2)$ & 1 \\
\hline Elevated CRP & $67 / 117(57.3)$ & $59 / 121(48.8)$ & 0.19 \\
\hline Elevated AST & $65(44.8)$ & $74(50.3)$ & 0.35 \\
\hline Elevated ALT & $21(14.6)$ & $30(20.4)$ & 0.22 \\
\hline Elevated Bilirubin & $19(13)$ & $15(10.2)$ & 0.47 \\
\hline $\begin{array}{l}\text { Elevated Alkaline } \\
\text { Phosphatase }\end{array}$ & $25(17.2)$ & $16(10.9)$ & 0.13 \\
\hline
\end{tabular}

LDH: Lactate Dehydrogenase; CRP: C-reactive protein; AST: Aspartate aminotransferase; ALT: Alanine aminotransferase 
Table 3: Outcomes data on hospitalized COVID-19 patients according to their red blood cell distribution width (RDW) value

\begin{tabular}{|l|l|l|l|}
\hline \multicolumn{1}{|c|}{ Characteristic } & \multicolumn{1}{|c|}{$\begin{array}{c}\text { RDW Elevated Group } \\
\mathbf{N = 1 4 6}\end{array}$} & $\begin{array}{c}\text { RDW normal group } \\
\mathbf{N = 1 4 8}\end{array}$ & P-value \\
\hline In-hospital Mortality & $34(23.3)$ & $22(15.1)$ & 0.10 \\
\hline Shock & $55(37.7)$ & $38(25.7)$ & 0.03 \\
\hline Mechanical Ventilation & $29(19.9)$ & $20(13.5)$ & 0.19 \\
\hline
\end{tabular}

Table 4: Multivariable Logistic Regression Analysis of elevated red blood cell distribution width (RDW) value

\begin{tabular}{|l|l|l|}
\hline Variables & $\begin{array}{l}\text { Adjusted Odds Ratio (aOR) with 95\% } \\
\text { Confidence Interval (CI) }\end{array}$ & P-value \\
\hline \multicolumn{1}{|c|}{ Model 1 $^{€}$} & 0.010 \\
\hline Death & $4.5(1.4-14.3)$ & 0.010 \\
\hline Septic Shock & $4.6(1.4-15.1)$ & 0.191 \\
\hline Mechanical Ventilation & $2.1(0.7-6.5)$ & 0.018 \\
\hline \multicolumn{1}{|c|}{ Model 2 $^{\mathbf{f}}$} & 0.016 \\
\hline Death & $5.5(1.3-22.8)$ & 0.576 \\
\hline Septic Shock & $5.4(1.3-21.1)$ & \\
\hline Mechanical Ventilation & $1.4(0.4-4.9)$ &
\end{tabular}

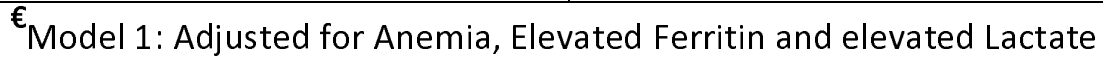

${ }^{f}$ Model 2: Adjusted for Age, Gender, Body mass index, coronary artery disease, Hypertension, Diabetes Mellitus, Chronic Obstructive Pulmonary Disease, Anemia, Elevated Ferritin and elevated Lactate 


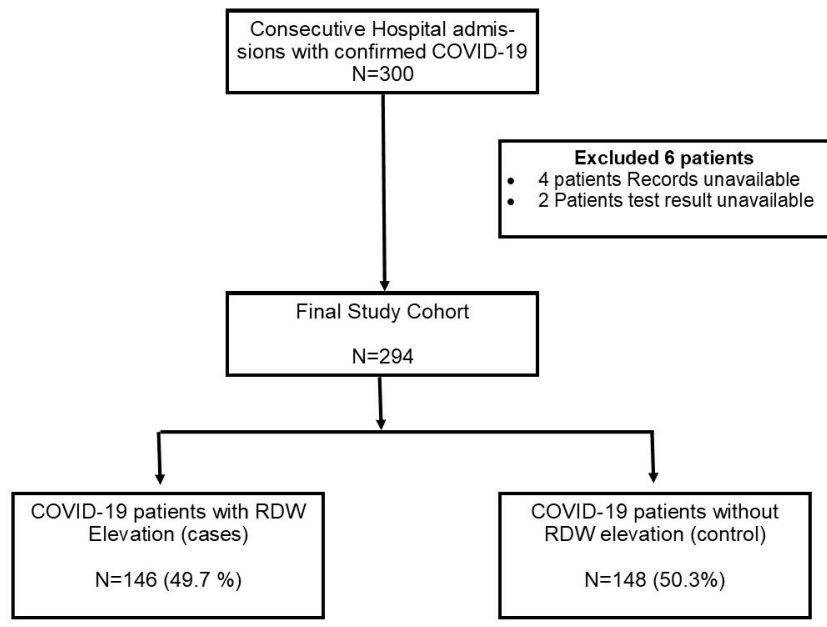


Roc Curve

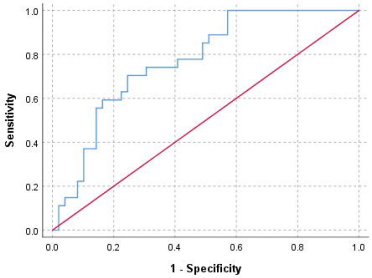




\section{ROC Curve}

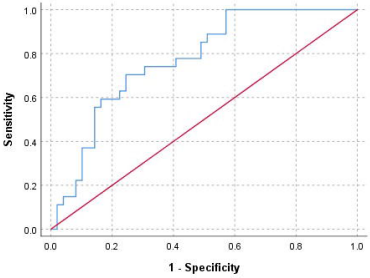

